\title{
ENFORCEABILITY AND THE RESOLUTION OF INTERNATIONAL JURISDICTIONAL CONFLICTS: COMMENTS ON ABBOTT, ATWOOD, AND ORDOVER
}

\author{
Edward Tower* and Thomas D. WilletT $\dagger$
}

\section{INTRODUCTION}

The three articles by Abbott, Atwood, and Ordover illustrate the importance of combining economic, political, and legal analyses in considering issues of international economic relationships and also the difficulties inherent in doing so. The international dimension to such issues often complicates not only the analysis of the economic effects of alternative legal and political strategies, but also the enforceability of such strategies, as well as the types of rules upon which agreement might be reached. The widely differing conclusions drawn by Atwood and Ordover about the most desirable strategy for applying U.S. antitrust laws against cartel-type behavior abroad illustrate the difficulties in successfully combining these considerations. Both authors clearly emphasize, as does Abbott, that in a world characterized by international rivalry as well as cooperation among sovereign governments, neither economic nor legal theory by itself provides a sufficient guide for analysis. Both the lawyer, Atwood, and the economist, Ordover, indicate concerns with economic effects and with issues of enforceability, but they do not carry through their analysis of the balancing of these considerations in a fully consistent manner.

\section{II}

The Difficulties of Enforcing Antitrust Statutes Abroad

Ordover's discussion of the ways in which U.S. economic interests would be influenced by different types of industrial policies abroad is interesting. Nevertheless, Professor Wood's skepticism in her comments about the practicality of distinguishing between different policies as a basis for legal

\footnotetext{
Copyright (C) 1988 by Law and Contemporary Problems

- Professor of Economics, Duke University.

$\dagger$ Horton Professor of Economics, Claremont McKenna College and Claremont Graduate School; Director, Claremont Center for Economic Policy Studies.
} 
determinations seems well-founded. ${ }^{1}$ Equally important is the issue of whether U.S. antitrust law findings could be effectively enforced against actions taken abroad by foreign firms, and even if so, would this be the most effective way to try to deal with such conflicts.

Ordover acknowledges the impossibility of suing foreign governments in their sovereign capacity, ${ }^{2}$ but goes on to argue that while "very few advantages will result from an aggressive exercise of jurisdiction in cases alleging violations of section 2 of the Sherman Act . . claiming jurisdiction in section 1 cases promises clear economic benefits." 3 He argues that by "aggressively using section $1 \ldots$ we might encourage foreign governments to rebate the overcharge and benefit U.S. consumers." If the decisions of the courts of the United States could be effectively enforced and the only concern was with what is economically desirable from the standpoint of the United States, then Ordover's comments on section 1 actions would be very persuasive. However, such backing of the American court's findings by the government of the country where the cartel is located seems unlikely, especially where the foreign government was instrumental in setting up the cartel in the first place. As is documented in the appendix to this comment, a wide range of sanctions against foreign firms exist under U.S. law. Unfortunately, the options which can have the strongest effects when taken unilaterally impose substantial direct costs on the U.S. economy or run the serious risk of inducing retaliation abroad. For example, where the cartel members have assets in the United States, these can be frozen and used to pay assessed fines and damages. Freezing assets and assessing fines and damages are extremely strong acts, however, which should not be undertaken without careful consideration of the likely repercussions. Evaluating the appropriate response is a task for which the executive branch is far better equipped than the judiciary. ${ }^{5}$

The most general, clearly enforceable sanction is to forbid sales to the United States by the foreign firms concerned, but that would only add to the costs to the U.S. economy of the original restrictions in supply. As Ordover discusses, there is an asymmetry in our ability through national actions to combat inappropriately priced imports. ${ }^{6}$ It is easy to place duties on items priced too low and thus increase the price. Where prices are too high, however, price correction would require the home government to subsidize imports, increasing profits for the foreign producers of the overpriced goods. ${ }^{7}$ This is not an attractive option. Policies should attempt to lower the foreign

1. Wood, Conflicts of Jurisdiction in Antitrust Law: A Comment on Ordover and Atwood, LAw \& Contemp. Probs., Summer 1987, at 185.

2. Ordover, Confict of Jurisdiction: Antitrust and Industrial Policy, Law \& Contemp. Probs., Summer 1987, at 167.

3. Id. at 177 .

4. Id. at 171 .

5. For an interesting discussion of the role which the freezing of Iranian assets in the United States played in solving the Iranian Hostage Crisis, see B. CoHEN, IN Whose INTEREST? (1986).

6. Ordover, supra note 2, at 175.

7. Id. at 175 . 
monopoly price instead. How best to do this is a complicated issue and the best strategy may vary on a case-by-case basis. Alternatives include imposing a tariff to lower the monopoly's profit-maximizing price, direct bargaining, and threatening retaliation. Where the foreign monopoly price is due to a cartel, doing nothing or merely adopting non-confrontational measures to reduce the price at which foreigners can sell a given amount to the domestic market may be the best strategy. The rationale for such an approach would be to help undermine the cohesion of the cartel by avoiding political actions, which would increase cartel solidarity, while increasing the market pressures on the cartel in hopes of stimulating greater free riding and ultimately a breakdown of the cartel. Optimal policy strategies which take the cartel as a given can differ quite substantially from those designed to break the cartel. ${ }^{8}$

\section{III}

\section{ENFORCEABILITY AND THE NEED for Government-To-Government Negotiations}

Prosecution will seldom be the best way to influence the behavior of foreign governments. Atwood correctly observes that "disputes over the activities of government sanctioned export cartels should be addressed on a government-to-government basis rather than through litigation in national courts under national rules."'9 Successful "dispute settlement" activities require the careful balancing of a wide range of considerations including strategic assessments of the likely reactions of foreign governments. Neither in terms of the capacity to make such judgments nor in terms of the range of instruments of persuasion which can be brought to bear are the courts well placed to deal with such issues. The outcome of direct government-togovernment negotiations will on average be more satisfactory.

It is important to distinguish between one's objectives and the best way to achieve them. The case for not applying U.S. antitrust laws to the actions of foreign firms outside of the United States rests on the issue of enforceability. Contrary to the views expressed by Ordover, Atwood's argument opposing the enforcement of U.S. antitrust laws against national cartels abroad does not logically imply that there should be "mutual forbearance among trading nations with respect to their home-grown export cartels." 10 Rather, it reflects

8. For evaluations of alternative strategies toward foreign monopoly, see Dreyer, Counteruailing Foreign Use of Monopoly Power, in Challenges to a Liberal InTERnational Economic Order 317 (R. Amacher, G. Haberler \& T. Willett eds. 1979) (includes commentaries by Holzman, Tollison, Caves, Diaz-Alejandro, Shields, and Tower). See also Tower, Making the Best lise of Trade Restrictions in the Presence of Foreign Market Power, 15 J. INT'L Econ. 349 (1983). For specific discussion of policies toward OPEC, see Willett, Oil Import Quotas Are Not the Answer, J. EnERGy \& Dev. 240 (1976); Willett, The Structure of OPEC and the Outlook for International Oil Prices, 2 WORLD ECON. 51 (1979); Willet, Conflict and Cooperation in OPEC: Some Additional Economic Considerations, 33 INT'L OrG. (1979).

9. Atwood, Conficts of Jurisprudence in the Antitrust Field: The Example of Export Cartels, LAw \& Contemp. Probs., Summer 1987, at 162.

10. Ordover, supra note 2, at 172. 
the difficulty of using national antitrust laws as a method of dealing with the problem.

Atwood's logic falters when he proposes distinguishing between national and international export cartels for the purpose of enforcing U.S. antitrust policies. While the latter type of cartel presents far more serious problems, the problems of effective enforcement continue to apply. There may be more concern about OPEC than the French wine cartel, but in both cases national antitrust laws fail to provide an effective response. In each case, the most desirable outcome would be effective international legal agreements prohibiting such actions. Where such agreements cannot be secured, the United States is left with direct negotiation and bargaining as the best approach in most circumstances.

\section{IV}

\section{Hard Versus Soft InTERnational LaW ${ }^{11}$}

There exists an argument for passing some laws and adopting some agreements even though it is known that they have no effective enforcement mechanism. Such "soft" international law can be seen as enunciating principles or objectives which generate moral suasion. This possibility of moral suasion, however, must be balanced against the chances that continued ineffectiveness of laws will breed disrespect for them. There are doubts about Atwood's argument that his proposed enforcement stance "would help legitimize U.S. enforcement efforts against cartels that do not meet the listed criteria." 12 Certainly, one can support the principle that it may often be wiser to agree on more limited objectives which can be achieved, than to continue to strive for a more desirable goal whose realization is unlikely. In these terms, however, Atwood's proposal buys the United States very little.

\section{V}

\section{ENFORCEABILITY AND DUAL JURISDiction}

Abbott's analysis of extraterritorial trade controls gives an excellent example of the need to consider enforcement issues. ${ }^{13}$ Continual bargaining is costly and the absence of clear ground rules creates uncertainty. ${ }^{14}$ Thus, assuming the adoption of sensible criteria, it is desirable to attempt to negotiate strong international codes and agreements. ${ }^{15}$ Abbott presents a very useful discussion of the types of provisions that might form the basis for

11. For discussions of the concept of soft law, see Gold, Strengthening the Soft International Law' of Exchange Arrangements, 77 AM. J. INT'L L. 443 (1983); Wijkman, Informal Systemic Change in the G.ATT, 9 WORLD ECON. 37 (1986); Farran, The Interplay of Lau and Economics in International Trade Regulation, in Issues in World Trade Policy 193 (R. Snape ed. 1986).

12. Atwood, supra note 9 , at 163 .

13. Abbott, Collective Goods, Mobile Resources, and Extraterritorial Trade Controls, LAw \& ConTEMP. Probs., Summer 1987, at 117.

14. Id. at 146 .

15. Id at 147-48. 
an agreement between the United States and Europe on the permissible reach of national trade controls. As a general principle, such issues should be approached on the basis of dual jurisdiction, with the last word belonging to the government with the more effective enforcement possibilities. Thus, in the case of sanctions, it would be argued that it is legitimate for the United States to apply its sanctions policies to the foreign subsidiaries of U.S. firms, but that host country governments would have the right to override such policies. This would provide a clear legal framework for government-togovernment negotiations about sanctions policies without creating additional jurisdictional acrimony.

\section{VI}

\section{The Desirability of Enforceable Property Rights}

As is emphasized in the Coasian approach to law and economics, where bargaining is possible, the most important factor involved in achieving efficient outcomes is that the legal framework of "property rights" (in this case the property right of jurisdiction) be clearly established in an enforceable manner. ${ }^{16}$ Whether the right to decide is given to party $A$ or party $B$, there will be both opportunity and incentive to bargain for the most highly valued outcome. There still would remain free-riding problems, among others, which may cause conflict, but there would be a clear focal point for negotiations. Following the spirit of Abbott's suggestions, it seems desirable to provide a process whereby the initiating country's government will inform the governments of countries where affected subsidiaries reside of its intentions, before they are made public. The host country's government could then inform the initiating country that it was seriously considering overriding the initiating government's intentions before making any public announcement. This would facilitate productive negotiations by keeping initial public announcements from hardening either country's positions.

\section{VII}

\section{Conclusion}

In conclusion, it should be emphasized that while this article criticizes some of the specifics of the papers discussed, it is heartening to see the recognition being given to the need to combine economic, political, and legal analyses in dealing with policy issues concerning international economic relations. These papers make a useful contribution to the growth of this literature.

16. The original contribution is Coase, The Problem of Social Costs, 3 J.L. \& Econ. 1 (1960). For recent applications and references to other literature applying this law-and-economics approach and the closely related public choice approach to issues of national versus international jurisdiction and the design of strategies to deal with international spillover, see R. ECKERT, ThE ENCLOSURE OF OCEAN ResourCes (1979); Tollison \& Willet, Institutional Mechanisms for Dealing with International Externalities: A Public Choice Perspective, in The Law of THE Sea 77 (R. Amacher \& R. Sweeney eds. 1976); Conybeare, International Organization and the Theory of Property Rights, 34 INT'L ORG. 307 (1980). 